\title{
Konsep Perbankan Syari'ah Dalam Mewujudkan Pembangunan Nasional Yang Berkeadilan (Tinjauan Sosiologi Hukum Islam)
}

\author{
Iri Hamzah ${ }^{1}$ \\ Institut Agama Islam Yasni Bungo \\ Email: erihamzah80@gmail.com
}

Muhammad Said Yusuf ${ }^{2}$

PascaSarjana UIN Sunan kalijaga, Yogyakarta

Email: msysf14@gmail.com

\author{
Shirhi Athmainnah ${ }^{3}$ \\ PascaSarjana UIN Sunan kalijaga, Yogyakarta \\ Email: shirhi2015@gmail.com
}

\begin{abstract}
The purpose of syari'ah banking is to support the implementation of development (national and regional) which is directed towards the realization of increased justice, togetherness, and equitable distribution of people's welfare in economic activities.The purpose of establishing the Syari'ah Bank was directed at improving justice, togetherness, and equitable distribution of people's welfare. This objective is stated in article 3 of Law no. 21 2008.Sociology of law discusses the mutual influence between changes in law and society. Changes in law can affect changes in society,and vice versa changes in society can lead to changes in law, With the existence of Law no. 21 of 2008 (especially Article 3), the public is very enthusiastic about using the Islamic banking system togetherBased on Indonesian syari'ah banking data, the growth of conventional banking is far behind that of syari'ah banks where syari'ah banks have experienced growth of around 40 percent per year in the last 10 years while conventional banking is only 20 percent
\end{abstract}

Keywords: Islamic Banking, National Development, Sociology of Islamic Law

\begin{abstract}
Abstrak
Tujuan dari perbankan syari'ah adalah menunjang pelaksanaan pembangunan (nasional dan daerah) yang diarahkan kepada terwujudnya peningkatan keadilan, kebersamaan, dan pemerataan kesejahteraan rakyat dalam kegiatan ekonomi. Tujuan dibangunya Bank Syari'ah adalah diarahkan dalam rangka meningkatkan keadilan, kebersamaan, dan pemerataan kesejahteraan rakyat. Tujuan ini tercantum dalam pasal 3 Undang Undang No. 21 2008.Sosiologi hukum membahas pengaruh timbal balik antara perubahan hukum dan masyarakat. Perubahan hukum dapat mempengaruhi perubahan masyarakat, dan sebaliknya perubahan masyarakat dapat menyebabkan terjadinya perubahan hukum. Dengan adanya UU No. 21 Tahun 2008 (khususnya Pasal 3), maka sangat nampak geliat masyarakat untuk berduyun-duyun menggunakan sistem perbankan islam. Berdasarkan data perbankan syari'ah Indonesia pertumbuhan perbankan konvensional jauh ketinggalan oleh bank syari'ah dimana bank
\end{abstract}

\footnotetext{
${ }^{1}$ Penulis adalah Dosen Tetap IAI Yasni Muara Bungo

${ }^{2}$ Alumni Pasca Sarjana UIN Sunan kalijaga Yogyakarta, Jurusan Hukum Keluarga Islam

${ }^{3}$ Alumni Pasca Sarjana UIN Sunan kalijaga Yogyakarta, Jurusan Hukum Keluarga Islam
} 
Iri Hamzah, Muhammad Said Y, Shirhi Athmainnah : Konsep Perbankan Syari'ah ...

syari'ah mengalami pertumbuhan sekitar 40 persen pertahun dalam 10 tahun terakhir sementara perbankan konvensional hanya 20 persen.

Kata Kunci: Perbankan Syariah, Pembagunan nasional, Sosiologi Hukum Islam

\section{A. Pendahuluan}

Pembangunan nasional adalah upaya untuk meningkatkan seluruh aspek kehidupan masyarakat, bangsa dan negara yang sekaligus merupakan proses pengembangan keseluruhan sistem penyelenggaraan negara untuk mewujudkan Tujuan Nasional. Dalam pengertian lain, pembangunan nasional dapat diartikan sebagai rangkaian upaya pembangunan yang berkesinambungan dan meliputi seluruh kehidupan masyarakat, bangsa, dan negara untuk melaksanakan tugas mewujudkan Tujuan Nasional. ${ }^{4}$ Adapun yang dimaksud dengan Tujuan Nasional adalah sasaran segala kegiatan suatu bangsa yang perwujudannya harus diusahakan secara terus menerus.Tujuan nasional bangsa indonesia tercantum dalam alenia keempat Pembukaan UUD 1945 yang berbunyi "kemudian dari pada itu untuk membentuk suatu pemerintahan negara Indonesia dan seluruh tumpah darah Indonesia, untuk memajukan kesejahteraan umum, mencerdaskan kehidupan bangsa, dan ikut melaksanakan ketertiban sunia yang berdasarkan kemerdekaan, perdamaian abadi, dan keadilan sosial".

Langkah awal untuk mewujudkan tujuan nasional adalah dengan mengupayakan pembangunan dari seluruh aspek kehidupan, tidak terkecuali dalam aspek ekonomi. Secara kasat mata, berhasil tidaknya pembangunan sebuah Negara, salah satunya diukur dari pertumbuhan ekonominya. Sebut saja China. Pertumbuhan ekonomi China melambung lagi pada kuartal ketiga tahun ini, sehingga meringankan tekananan untuk mengeluarkan stimulus lagi dan membuat para pemimpin negara itu fokus pada reformasi jangka panjang. ${ }^{5}$ Lahirnya Perbankan Syari'ah berawal dari lokakarya "Bungo Bank dan Perbankan" yang diselenggarakan MUI pada tanggal 18-20 Agustus 1990 di Cisarua. Ide ini kemudian lebih dipertegas lagi dalam Munas IV MUI di Hotel Sahid Jaya Jakarta tanggal 22-25 Agustus 1990. Atas dasar amanat Munas IV MUI inilah langkah untuk mendirikan Bank Islam di Indonesia dimulai.

Peran Perbankan Syari'ah di Indonesia kerap disebut-sebut sebagai salah satu unsur penyumbang pembangunan nasional dengan ciri khasnya yaitu menerapkan sistem nir-bunga. Bagaimana upaya perbankan syari'ah dalam mewujudkan pembangunan nasional. Khusunya dalam bidang ekonomi? Tulisan ini dengan seperangkat alat analisis yang ada, mencoba memaparkan peran perbankan syari'ah dengan berpijak pada Pasal 3 UU No. 21 Tahun 2008 tentang Perbankan Syari'ah, yang secara tegas menyebutkan bahwa Perbankan Syari'ah bertujuan menunjang pelaksanaan pembangunan nasional dalam rangka meningkatkan keadilan, kebersamaan, dan pemerataan kesejahteraan rakyat.

\footnotetext{
${ }^{4}$ Luthfi Lubihanto, Optimalisasi Pendidikan Politik Masyarakat Guna Pengembangan Demokrasi dalam Rangka Pembagunan Nasional, kertas karya perorangan (Taskap) Program Pendidikan Reguler Angkatan XLIX lembaga ketahanan RI, 2013 ) hal 24

${ }^{5}$ Ibid hal 25
} 
Iri Hamzah, Muhammad Said Y, Shirhi Athmainnah : Konsep Perbankan Syari'ah ...

\section{B. Landasan Teori}

\section{Praktik Perbankan Syari'ah di Masa Nabi Muhammad dan Sahabat}

Secara umum, bank adalah lembaga yang melaksanakan tiga fungsi utama, yaitu menerima simpanan uang, meminjamkan uang, dan memberikan jasa pengiriman uang. Di dalam sejarah perekonomian umat islam, pembiayaan yang dialkukan dengan akad yang sesuai syari'ah telah menjadi bagian dari tradisi umat Islam sejak zaman Nabi. Ptaktik-praktik seperti menerima titipan harta, meminjamkan uang untuk meperluan komsumsi dan keperluan bisnis, serta melakukan pengiriman uang, telah lazim dilakukan sejak zaman Rasulullah Saw. ${ }^{6}$

Rasulullah Saw, yang dikenal dengan julukan al-amin, dipercaya oleh masyarakat Makkah menerima simpanan harta, sehingga pada saat terakhir sebelum hujrah ke Madinah, ia meminta Ali bin Abi Thalib untuk mengembalikan semua titipan itu kepada para pemiliknya. Dalam konsep ini, pihak yang dititipi tidak dapat memanfaatkan harta titipan.seorang sahabat Rasulullah Saw, Zubair bin al-Awwam r.a., memilih tidak menerima titipan harta. Ia lebih suka menerimanya dalam bentuk pinjaman. Tindakan Zubair ini menimbulkan implikasi yang berbeda, yakni pertama, dengan mengambil uang itu sebagai pinjaman, ia mempunyai hak untuk memanfaatkannya; kedua, karena bentuknya pinjaman, ia berkewajiban untuk mengembalikan secara utuh. ${ }^{7}$

Penggunaan cek juga sudah dikenal luas sejalan dengan meningkatnya perdagangan antara negeri Syam dengan Yaman, yang paling tidak berlangsung dua kali dalam setahun. Bahkan, pada masa pemerintahannya, Khalifah Umar bin alKhattab r.a. menggunakan cek untuk membayar tunjangan kepada mereka yang berhak. Dengan menggunakan cek ini, mereka mengambil gandum di Baitul Mal yang ketika itu diimpor dari Mesir. Di samping itu, pemberian modal untuk modal kerja berbasis bagi hasil, seperti mudharabah, muzara'ah, musaqah, telah dikenal sejak awal di antara kaum Muhajirin dan kaum Anshar. ${ }^{8}$

Beberapa istilah perbankan modern bahkan berasal dari khazanah ilmu fikih, seperti istilah kredit ( Inggris: credit, Romawi: credo) yang diambil dari istilah qard - credir dalam bahasa inggris berarti meminjamkan uang: credo berarti kepercayaan: sedangkan qard dalam fikih berarti meminjamkan uang atas dasar kepercayaan. ${ }^{9}$

\section{Sejarah Singkat dan Perkembangan Perbankan di Indonesia}

Ide konkrit pendirian Bank Islam berawal dari lokakarya "Bunga Bank dan Perbankan" yang diselenggarakan MUI pada tanggal 18-20 Agustus 1990 di Cisarua. Ide ini kemudian lebih dipertegas lagi dalam Munas IV MUI di Hotel Sahid Jaya Jakarta tanggal 22-25 Agustus 1990. Atas dasar amanat Munas IV MUI inilah langkah untuk mendirikan Bank Islam di Indonesia dimulai.

\footnotetext{
${ }^{6}$ Adiwarman A. Karim. Bank Islam: Analisis Fiqih Dan Keuangan,(Jakarta: Pt Rajagrafindo Persada, 2007). hlm. 18

${ }^{7}$ Ibid., hlm. 18-19

${ }^{8}$ Ibid., hlm. 19

${ }^{9}$ Ibid.
} 
Iri Hamzah, Muhammad Said Y, Shirhi Athmainnah : Konsep Perbankan Syari'ah ...

Bank Syari'ah lahir sebagai salah satu solusi alternatif terhadap pertentangan antara bunga bank dan riba. Dengan demikian, kerinduan umat Islam Indonesia yang ingin melepaskan diri dari persoalan riba telah mendapat jawaban dengan lahirnya bank Islam. Bank Islam lahir di indonesia yang gencarnya, pada sekitar tahun 1990-an atau tepatnya setelah ada Undang-Undang no. 7 tahun 1992, yang direvisi dengan Undang-Undang Perbankan No. 10 tahun 1998, dalam bentuk sebuah bank yang beroperasinya dengan sistem bagi hasil atau bank Syari'ah. ${ }^{10}$

Perkembangan perbankan Syari'ah di Indonesia masih dirasa lambat dibanding dengan Negara-negara Muslim lainnya, namun perbankan Syari'ah di Indonesia akan terus berkembang. Bila pada periode umum 1992-1998 hanya ada satu unit Bank Syari'ah, maka pada tahun 2005, jumlah bank syari'ah di Indonesia telah bertambah menjadi 20 unit, yaitu 3 bank umum syari'ah dan 17 unit usaha syari'ah. Sementara itu, jumlah Bank Perkreditan Rakyat Syari'ah (BPRS) hingga akhir tahun 2004 bertambah menjadi 88 buah. ${ }^{11}$

Perkembangan perbankan Syari'ah telah menjadi tolak ukur keberhasilan eksistensi ekonomi syari'ah. Bank Muamalat sebagai bank Syari'ah pertama dan menjadi pioneer bagi bank Syari'ah lainnya telah lebih dahulu menerapkan sistem ini di tengah menjamurnya bank-bank konvensional. Krisis moneter yang terjadi pada tahun 1998 telah menenggelamkan bank-bank konvensional dan banyak dilikuidasi karena kegagalan sistem bunganya. Sementara perbankan yang menerapkan sistem syari"ah dapat tetap eksis dan mampu bertahan. Tidak hanya itu, ditengah-tengah krisis keuangan global yang melanda dunia pada penghujung akhir tahun 2008, lembaga keuangan syari'ah kembali membuktikan daya tahannya dari terpaan krisis. Lembaga-lembaga keuangan syari'ah tetap stabil dan memberikan keuntungan, kenyamanan, serta keamanan bagi para pemegang sahamnya, pemegang surat berharga, peminjam dan para penyimpan dana di bankbank Syari'ah. Hal ini dapat dibuktikan dari keberhasilan bank Muamalat melewati krisis yang terjadi pada tahun 1998 dengan menunjukkan kinerja yang semakin meningkat dan tidak menerima sepeser pun bantuan dari pemerintahan dan pada krisis keuangan pada tahun 2008, bank Muamalat bahkan mampu memperoleh laba Rp 300 miliar lebih. ${ }^{12}$

\section{Perbankan Syari'ah dan Pembangunan Nasional}

Berbeda dengan tujuan bank yang pada umumnya menekankan peningkatan pemerataan, pertumbuhan ekonomi dan stabilitas nasional ke arah peningkatan kesejahteraan rakyat banyak, tujuan perbankan syari'ah diarahkan dalam rangka meningkatkan keadilan, kebersamaan, dan pemerataan kesejahteraan rakyat. Tujuan ini tercantum dalam pasal 3 Undang-Undang No 21 Tahun 2008.

${ }^{10}$ Muhammad. Manajemen Bank Syari'ah, edisi revisi, cet. II. (Yogyakarta:UPP SKIM YKPN, 2011), hlm.

${ }^{11}$ Adimarwan A. Karim. Bank Islam... ......, hlm.25

${ }^{12}$ http://www.slideshare.net/mobile/partysioketoj/perkembangan-bank-syariah, akses: 30 november 2013 
Iri Hamzah, Muhammad Said Y, Shirhi Athmainnah : Konsep Perbankan Syari'ah ...

"perbankan Syari'ah bertujuan menunjang pelaksanaan pembangunan nasional dalam rangka meningkatkan keadilan, kebersamaan, dan pemerataan kesejahteraan rakyat."

Dalam penjelasan Pasal 3 Undang-Undang Nomor 21 Tahun 2008 dinyatakan sebagai berikut:

"dalam mencapai tujuan penunjang pelaksanaan pembangunan nasional, Perbankan Syari'ah tetap berpegangpada prinsip syari'ah secara menyeluruh (kaffah) dan konsisten (istiqamah)."

Dengan demikian jelas, bahwa tujuan dari perbankan syari'ah adalah menunjang pelaksanaan pembangunan (nasional dan daerah) yang diarahkan kepada terwujudnya peningkatan keadilan, kebersamaan, dan pemerataan kesejahteraan rakyat dalam kegiatan ekonomi. Oleh karena itu, implementasi prinsip syari'ah dalam kegiatan usaha perbankan syari'ah harus dilaksanakan secara kaffah dan istiqamah, sehingga dapat tercipta keadilan, kebersamaan, dan pemerataan dalam kegiatan ekonomi.

Pembangunan adalah usaha untuk menciptakan kemakmuran dan kesejahteraan lahir batin secara adil dan merata bagi seluruh rakyat indonesia. Oleh karena itu, maka pembangunan harus dilaksanakan oleh pemerintah dan seluruh lapisan masyarakat dengan meningkatkan produksi yang cukup tinggi, sehingga makin tinggi pola kemampuan ekonomi dan mantap kestabilan nasional. ${ }^{13}$ Pembangunan Nasional diselenggarakan berdasarkan demokrasi dengan prinsipprinsip kebersamaan, berkeadilan, berkelanjutan, berwawasan lingkungan, serta kemandirian dengan menjaga keseimbangan kemajuan dan kesatuan Nasional. ${ }^{14}$

Tujuan pembangunan nasional adalah mewujudkan suatu masyarakat yang adil dan makmur dalam sesama perikehidupan bangsa yang aman, tentram, tertib dan dinamis dalam lingkungan pergaulan dunia yang merdeka, bersahabat, tertib dan damai. Pembangunan tidak semata ditekankan pada fisik semata, tetapi juga subjek pembangunan tidak kalah penting untuk ditekankan, yakni manusianya itu sendiri. Semua usaha pada tiap tahapan pembangunan hendaknya semakin mendekatkan kepada tujuan tersebut dan tiap generasi dapat mewariskan keadaan yang lebih baik kepada generasi berikutnya, sehingga tujuan pembangunan nasional yang dicita-cita bangsa indonesia menjadi suatu kenyataan. ${ }^{15}$

Pembangunan strategi salah satu indikator kemajuan suatu negara merupakan salah satu hal penting yang tidak bisa dilepaskan dari peran bank-bank nasional khususnya Bank Syari'ah. Bank Syari'ah cukup bisa diandalkan dalam proses mencapai kesejahteraan dan keadilan serta kemakmuran masyarakat. Hal ini dikarenakan bahwa Bank Syari'ah menerapkan prinsip bagi hasil yang berkeadilan tanpa menerapkan bunga atas transaksi . bank Syari'ah yang dalam transaksinya mengharamkan bunga atas memberikan pelajaran bahwa hak orang

\footnotetext{
${ }^{13}$ Mansur, Pandangan Islam Terhadap Pembangunan Nasional, (Dapatermen Agama R.I, 1981). hlm. 9.

${ }^{14}$ Pasal 2 ayat (1) Undang-Undang Nomor 25 Tahun 2004 Tentang Sistem Perencanaan Pembangunan Nasional

${ }^{15}$ Mansur. Pandangan Islam ......, hlm. 7.
} 
lain tidak boleh kita miliki. Riba dengan segala macam jenisnya jelas merugikan, karena terlihat adanya kesenjangan dan ketidakadilan dalam pembagian hasil. Tingkat suku bunga hanya membuat kacau pembangunan. Hal itu terlihat ketika masa krisis moneter pada tahun 1998. Saat itu tingkat suku bunga yang tinnggi mengakibatkan kekacauan perekonomian dan menghambat proses pembangunan. Sementara Bank Syari'ah dengan keutamaannya yang berkeadilan mampu bertahan. Hal itu sudah jelas-jelas membuktikan bahwa Bank Syari'ah adalah pilihan yang tepat untuk meningkatkan pembangunan kita. Tapi, tentunya Bank Syari'ah tidak bekerja sendirian, karena dukungan penuh dari pemerintah dan masyarakat juga sangat berdampak besar dalam memajukan kinerja Bank Syari'ah yang pada akhirnya akan meningkatkan pembangunan di negara kita. Pemerintah harus berperan positif dan berorientasi pada sasaran di dalam ekonomi. Hal itu bukan suatu jenis peran yang akan mengarah pada pembentukan suatu tatanan totaliter, namun peran ini hanya bersifat komplementer yang dimainkan oleh pemerintah lewat internalisasi nilai-nilai Islam dalam masyarakat, penciptaan iklim sosio-ekonomi yang sehat dan pengembangan institusi yang tepat. ${ }^{16}$

Skema mekanisme proses pembangunan yang berdimensi keadilan dimulai dari konsensus nasional mengenai tujuan-tujuan pembangunan sampai dengan kebijaksanaan-kebijaksanaan pembangunan yang ditopang oleh perangkat kelembagaan masyarakat yang mencerminkan ciri-ciri yang bersih, efektif, dan demokratis. Tujuan-tujuan pembangunan dalam kerangka strategi pembangunan yang berdimensi keadilan di antaranya mencakup pemerataan pemenuhan kebutuhan pokok. Pemerataan pendidikan dan kesehatan, pemerataan kesempatan kerja, pemerataan berusaha dengan meningkatkan kesempatan pengusaha kecil dan golongan ekonoomi lemah, pemerataan berpartisipasi dalam pembangunan, pemerataan penyebaran pembangunan di seluruh indonesia, dan pemerataan memperoleh keadilan. ${ }^{17}$ Adapun kebijaksanaan-kebijaksanaan pembangunan yang diperlukan untuk merealisasikan tujuan-tujuan pembangunan tersebut di antaranya adalah kebijaksanaan sosial, kebijakan investasi, kebijakan moneter, dan lain sebagainya. Sedangkan komponen kelembagaan masyarakat yang akan menunjang pelaksanaan perangkat kebijaksanaan pembangunan tersebut terdiri dari struktur kekuasaan yang responsif dan accountable terhadap rakyat, representasi politik yang demokratis. Administrasi Negara yang bersih dan efektif, lembaga kontrol sosial yang bebas dan bertanggung jawab terhadap kepentingan rakyat, sistem hukum yang tegas dan non diskriminatif. ${ }^{18}$

Secara lebih terperinci, peran Bank Syari'ah dalam pembangunan di antaranya: ${ }^{19}$

a. Ekonomi syari'ah memberikan andil bagi perkembangan sektor rill. Diharamkannya suku bunga dan spekulasi mengharuskan dana yang dikelola

\footnotetext{
${ }^{16}$ M. Umar Chapra, Islam Dan Pembangunan Ekonomi, (Jakarta: Kencana, 2000). Hlm. 83.

${ }^{17}$ Mansur, Pandangan Islam Terhadap Pembangunan Nasional, (Dapatermen Agama R.I, 1981). hlm.9.

${ }^{18}$ Sritua Arief, Pembangunanisme Dan Edukasi Indonesia (Pemberdayaan Rakyat Dalam Arus Globalisasi).( Bandung: Zaman Wacana Mulia, 1998). hlm 244

${ }_{19}$ http://ramonauzunk13.blogspot.com/2012/02/peran-bank-syariah-dalam-pembangunan. html. diakses pada tanggal 25 november 2013.
} 
Iri Hamzah, Muhammad Said Y, Shirhi Athmainnah : Konsep Perbankan Syari'ah ...

oleh Bank Syari'ah disalurkan ke sektor rill dan usaha yang halal. Dengan penyaluran tersebut maka usaha sektor rill terbantu dan hal tersebut sudah membantu dalam pembangunan ekonomi bangsa.

b. Ekonomi syari'ah lewat industri keuangan syari'ah turut andil dalam menarik investai luar negeri ke Indonesia, terutama dari negara-negara Timur-tengah. Adanya berbagai peluang investasi syari'ah di Indonesia, telah menarik minat investor dari negara-negara petro-dollar ini untuk menanamkan modalnya di Indonesia.

c. Gerakan ekonomi syari'ah mendorong timbulnya perilaku ekonomi yang etis di kalangan masyarakat Indonesia. Ekonomi syari'ah adalah ekonomi yang berpihak kepada kebenaran dan keadilan dan menolak segala bentuk perilaku ekonomi yang tidak baik seperti sistem riba, spekulasi, dan ketidakpastian.

\section{Metode Penelitian}

Jenis pendekatan penelitian yang digunakan dalam penelitian ini adalah jenis pendekatan kuantitatif diskriptif dengan membandingkan antar variabael satu dengan yang lainnya. penulis menggunakan teknik Stratified Random Sampling. Stratified random sampling merupakan proses pengambilan sampel melalui proses pembagian populasi kedalam strata, memilih sampel acak sederhana dari setiap stratum, dan menggabungkannya ke dalam sebuah sampel untuk menaksir parameter populasinya. Sampel yang representatif adalah sampel yang benar-benar dapat mewakili karakteristik seluruh populasi. Jika populasi bersifat homogen, maka sampel bisa diambil dari populasi yang mana saja, namun jika populasi bersifat heterogen, maka sampel harus mewakili dari setiap bagian yang heterogen dari populasi tersebut sehingga hasil penelitian dari sampel dapat terpenuhi terhadap setiap anggota populasi.

\section{Hasil Penelitian dan Pembahasan}

\section{Konsep Keadilan John Rawls: Analisis Pasal 3 UU No. 21 Tahun 2008}

Menurut John Eawls, justice as fairness (keadilan sebagai kesetaraan). Artinya bahwa tidak seorang pun diperbolehkan mendominasi pilihan atau memanfaatkan kesempatan yang tidak adil seperti kelebihan dari anugerahalamiah atau posisi sosialnya. Kondisi ini menawarkan sebuah pilihan sejumlah prinsip pendistribusian hak dan kewajiban sekaligus keuntungan dan beban dari kerjasama sosial. Mereka memilih untuk menjadi masyarakat yang tertata baik, yaitu masyarakat yang di dalamnya mereka dapat berharap bahwa konsep keadilan yang dipilih benar-benar bersifat publik dan masyarakat hidup sesuai dengan aturan-aturannya. ${ }^{20}$

Teori ini sejalan dengan sistem perbankan syari'ah yakni di atas akad-akad yang telah disepakati bersama dengan prinsip tidak boleh merugikan dan juga tidak boleh membebankan kerugian bersama kepada salah satu pihak. Keuntungan

${ }^{20}$ Lebacqz, Karen, Teori-Teori Keadilan: Analisis Kritis Terhadap Pemikiran J.S Mill John Rawls, Robert Nozik, Reinhold Neibuhr, Jose Porfirio Miranda, Ter. Yuhdi Santoso,(Bandung: Nusa Media 2011), hlm. 50-53 
Iri Hamzah, Muhammad Said Y, Shirhi Athmainnah : Konsep Perbankan Syari'ah ...

menjadi keuntungan bersama, dan kerugian juga menjadi kerugian yang harus di tanggung bersama. ${ }^{21}$

Para ilmuan islam berpendirian bahwa tujuan bank islam bukan mencari keuntungan semata melainkan juga bersifat spsial. Pembiayaan dalam perbankan Islam menunjukkan dimensi kesejahteraan sosial. Artinya bahwa pembiayaan perbankan Islam harus disediakan untuk meningkatkan kesempatan kerja dan kesejahteraan ekonomi sesuai dengan nilai-nilai Islam. ${ }^{22}$ Pengimplementasikan tujuan perbankan syari'ah dapat dilihat di antaranya dengan: ${ }^{23}$

a. Mengarahkan kegiatan ekonomi umat untuk bermu'amalah secara islam.

b. Menciptakan suatu keadilan di bidang ekonomi, dengan jalan pemerataan melalui kegiatan investasi.

c. Untuk meningkatkan kualitas hidup dengan membuka peluang usaha yang diarahkan kepada kegiatan yang produktif menuju terciptanya kemandirian berusaha.

d. Membantu mengentaskan kemiskinan dengan berbagai pembinaan, seperti pembinaan pengusaha produsen, program pembinaan konnsumen, program pengembangan modal kerja dan program pengembangan usaha bersama.

e. Menjaga kestabilan ekonomi pemerintah. Dengan aktifitas-aktifitas bank Islam yang diharapkan mampu menghindarkan inflasi akibat penerapan sistem bunga, menghindarkan persaingan yang tidak sehar, dan menanggulangi kemandirian lembaga keuangan dari pengaruh gejolak moneter.

Tujuan perbankan syari'ah sebagaimana yang tercantum dalam Pasal 3 UndangUndang Nomor 21 Tahun 2008 sesuai dengan prinsip ekonomi syari'ah yang menekankan pada beberapa aspek, di antaranya: ${ }^{24}$

a. Aspek keadilan

Prinsip ini tercermin dari penerapan imbalan atas dasar bagi hasil dan pengambilan margin keuntungan yang disepakati bersama antara bank dan nasabah.

b. Aspek kemitraan

Bank Syari'ah menempatkan nasabah penyimpanan dana, nasabah pengguna dana, maupun bank pada kedudukan yang sama dan sederajatdengan mitra usaha. Hal ini tercermin dalam hak, keajiban, resiko dan keuntungan yang berimbang di antara mereka. Dalam hal ini bank berfungsi sebagai intermediary institution lewat skim-skim pembiayaanyang dimilikinya.

c. Aspek keterbukaan

${ }^{21}$ Ahmad Kamil, Kitab Undang-Undang Hukum Perbankan Dan Ekonomi Syari'ah.(Jakarta: Kencana Prenada Media Group, 2007), hlm. Iv.

${ }^{22}$ Suatu RemySjahdeini, , Perbankan Islam Dan Kedudukannya Dalam Tata HukumPerbankan Indonesia, Cet. III, (Jakarta: Pustaka Utama Grafiti, 2007), hlm. 21.

${ }^{23}$ WarkumSumitro , Asas-Asas Perbankan Islam Dan Lembaga- Lembaga Terkait (BAMUI, TAKAFUL Dan Pasar Modal Syarah'ah Di Indonesia,(Jakarta: Rajagrafindo Persada, 2004), hlm. 17-18.

${ }^{24}$ Lihat Dalam Atas Undang-Undang Republik Indonesia Nomor 21 Tahun 2008 Tentang Perbankan Syari'ah Dalam Ketentuan Umum Alinea Dua. 
Iri Hamzah, Muhammad Said Y, Shirhi Athmainnah : Konsep Perbankan Syari'ah ...

Melalui laporan keuangan bank yang terbuka secara berkesinambungan, nasabah dapat mengetahui tingkat keamanan dana dan kualitas manajemen bank.

d. Universalitas

Dalam mendukung operasionalnya bank tidak membeda-bedakan suku, agama, ras dan golongan dalam masyarakat dengan prinsip Islam sebagai rahmatan lil'alamiin.

e. Pengimplementasikan dari tujuan Perbankan syari'ah juga dapat dilihat dari fungsi perbankan syari'ah yang menghimpun dan menyalurkan dana masyarakat dalam rangka menjalankan fungsi bisnis sebagai lembaga intermediasi keuangan syari'ah. Ketentuan fungsi bisnis dari Bank Syari'ah dan UUS ini diatur dalam ketentuan Pasal 4 ayat (1) Undang-Undang Nomor 21 Tahun 2008, yang menetapkan bahwa: "Bank Syari'ah dan UUS wajib menjalankan fungsi menghimpun dan menyalurkan dana masyarakat."

Selain berkewajiban menjalankan fungsi penghimpun dana dan penyalur dana kepada masyarakat, Bank Syari'ah dan UUS masih mempunyai fungsi lain, yaitu fungsi sosial. Fungsi sosial keagamaan dari Bank Syari'ah dan UUS diatur dalam ketentuan Pasal 4 Undang-Undang Nomor 21 Tahun 2008 yang menetapkan sebagai berikut:

1. Bank Syari'ah dan UUS dapat menjalankan funngsi sosial dalam bentuk lembaga baitul mal, yaitu menerima dana yang berasal dari zakat, infak, sedekah, hibah, atau dana sosial yang menyalurkannya kepada organisasi pengelola zakat. ${ }^{25}$

2. Bank Syari'ah dan UUS dapat menghimpun dana sosial yang berasal dari wakaf uang dan menyalurkannya kepada pengelola wakaf dengan kehendak pemberi wakaf. ${ }^{26}$

Sesuai dengan penjelasan pasal 4 ayat (2) Undang Undang Nomor 21 Tahun 2008, perbankan syari'ah juga dapat menghimpun dana sosial lainnya, yaitu antara lain penerimaan bank yang berasal dari pengenaan sanksi terhadap nasabah. Dengan demikian, status Bank Syari'ah maupun UUS juga dapat disebut sebagai badan sosial masyarakat.

Sebagai langkah konkrit upaya pengembangan perbankan syari'ah di Indonesia, maka Bank Indonesia telah merumuskan sebuah Grand Strategy Pengembangan Pasar Pebankan Syari'ah, sebagai strategi komprehensif pengembangan pasar yang meliputi aspek-aspek strategis, yaitu: ${ }^{27}$

a. Menerapkan visi baru pengembangan perbankan syari'ah dengan membangun pemahaman perbankan syari'ah sebagai beyond banking.

\footnotetext{
${ }^{25}$ Pasal 4 ayat (2).

${ }^{26}$ Pasal 4 ayat (3).

${ }^{27}$ htt:// www.bi.go.id/web/id/perbankan/perbankan+syariah/. diakses 27 november 2013.
} 
Iri Hamzah, Muhammad Said Y, Shirhi Athmainnah : Konsep Perbankan Syari'ah ...

b. Program pencitraan baru perbankan syari'ah yang meliputi aspek positioning, differentiation, dan branding. Positioning baru bank syari'ah sebagai perbankan yang saling menguntungkan kedua belah pihak, aspek diferensiasi dengan keunggulan kompetitif dengan produk dan skema yang beragam, transparans, kompeten dalam keuangan dan beretika, teknologi informasiyang selalu up-date dan user friendly, serta adanya ahli investasi keuangan syari'ah yang memadai. Sedangkan pada aspek branding adalah "bank syari'ah lebih sekedar bank atau beyond banking".

c. Program pemetaan baru secara lebih akurat terhadap potensi pasar perbankan syari'ah yang secara umum mengarahkan pelayanan jasa Bank Syari'ah sebagai layanan universal atau bank bagi semua lapisan masyarakat dan semua segmen sesuai dengan strategi masing-masing bank syari'ah.

d. Program pengembangan produk yang diarahkan kepada variasi pruduk yang beragam yang didukung oleh keunikan value yang ditawarkan (saling menguntungkan) dan dukungan jaringan kantor yang luas dan penggunaan standar nama produk yang mudah dipahami.

e. Program peningkatan kualitas layanan yang didukung oleh Sumber Daya Manusia yang kompeten dan penyediaan teknologi informasi yang mampu memenuhi kebutuhan dan kepuasan nasabah serta mampu mengkomunikasikan produk dan jasa Bank Syari'ah kepada nasabah secara benar dan jelas, dengan tetap memenuhi prinsip syari'ah.

f. Program sosialisasi dan edukasi masyarakat secara luas dan efesien melalui berbagai sarana komunikasi langsung, maupun tidak langsung (mediacetak, elektronik, online/web-site), yang bertujuan untuk memberikan pemahaman tentang kemanfaatan produk serta jasa perbankan syari'ah yang dapat dimanfaatkan oleh masyarakat.

\section{Tinjauan Maqasid ash-Shari'ah terhadap Pasal 3 No. 21 Tahun 2008}

Dilihat dari sudut kerasulan Nabi Muhammad SAW, dapat diketahui bahwa syariat islam diturunkan oleh Allah adalah untuk mewujudkan kesejahteraan manusia secara keseluruhan. ${ }^{28}$ Maqasid ash-Shari'ah berarti tujuan Allah dan RasulNya dalam merumuskan hukum-hukum Islam. Tujuan itu dapat ditelusuri dalam ayat-ayat Al-Qur'an dan Sunnah Rasulullah sebagi alasan logis bagi rumusan suatu hukum yang berorientasi kepada kemaslahatan umat manusia. Sebagaimana dikemukakan oleh Abu Ishaq al-Syatibi bahwa tujuan pokok di syariatkan hukum islam adalah untuk kemaslahatan manusia baik di dunia maupun di akhirat kelak. Kemaslahatan yang akan diwujudkan itu menurut Abu Ishaq al-Syat ibi terbagi kepada tiga tingkatan, yaitu kebutuhan daruriyat, kebutuhan hajiyat, dan kebutuhan tahsiniyat. ${ }^{29}$ Kebutuhan daruriyat ialah tingkat kebutuhan yang harus ada atau disebut dengan kebutuhan primer. Bila tingkat kebutuhan ini tidak

\footnotetext{
${ }^{28}$ Koto, Alaiddin, Ilmu Fiqih Dan Ushul Fiqih, Jakartta: Rajawali Press, 2006.

${ }^{29}$ Asafria JayaBakri, Konsep Maqashid Syari'ah Menurut Al-Syatibi, (Jakarta: Pt Rajagrafindo Persada 1996), hlm. 72
} 
Iri Hamzah, Muhammad Said Y, Shirhi Athmainnah : Konsep Perbankan Syari'ah ...

terpenuhi, akan terancam keselamatan umat manusia baik di dunia maupun di akhirat kelak. Menurut al-Syat ibi ada lima hal yang termasuk dalam kategori ini, yaitu memelihara agama, memelihara jiwa, memelihara akal, memelihara kehormatan dan keturunan, serta memeliharaharta. Untuk memelihara lima pokok inilah Syariat Islam diturunkan. Setiap ayat hukum bila diteliti akan ditemukan alasan pembentukannya yang tidak lain adalah untuk memelihara lima pokok diatas.

Dalam kerangka kebutuhan daruriyat tersebut, maka Pasal 3 UU No. 21 Tahun $2008^{30}$ harus mmempunyai tujuan yang dapat meng-cover pemeliharaan agam, jiwa, akal, kehormatan dan keturunan, serta harta. Perbankan Syari'ah, yang secara khusus hanya bergerak pada bidang ekonomi (baca: harta), namun dalam perannya dapat juga mewujudkan pembangunan nasional.

Ekonomi syariah yang saat ini dipandang sebagai suatu sistem perekonomian yang mampu mendorong kesejahteraan masyarakat, sebagai salah satu alat pengentasan kemiskinan, mereduksi pengangguran, dan juga sebagai sistem ekonomi yang mendorong tercapainya cita-cita pembangunan nasional. Dengan ekonomi syariah, pembangunan berkualitas, inklusif dan berkeadilan dapat terus ditingkatkan.perkembangan ekonomi syariah di indonesia terus bertumbuh hingga mencapai rata-rata 40 persen setap tahunnya. Pertumbuhan ini lebih besar di bandingkan pertumbuhan ekonomi konvensional yang hanya tumbuh sebesar 19 persen. ${ }^{31}$

Perkembangan ekonomi syariah nasional dapat tercermin dari pertumbuhan aktivitas di sektor perbankan syariah, asuransi syariah, pasar modal syariah, lembaga keuangan mikro syariah dan pengelolaan zakat. Perkembangan ini juga memberi imbas yang cukup besar bagi pembangunan nasional khususnya di sektor riil seperti mendorong usaha mikro dan kecil, peningkatan pendapatan masyarakat, social security, social inclusivity, perluasan pasar lapangan kerja dan memperkokoh fundamentel ekonomi nasional. ${ }^{32}$

Di sektor perbankan syariah, data Bank Indonesia menunjukkan hingga akhir 2012 terdapat 11 Bank Umum Syariah (BUS), 24 Bank Syariah dalam bentuk Unit Usaha Syariah (UUS), dan 156 BPRS dengan jaringan kantor sebanyak 2.574 lokasi atau tumbuh sebesar 25.31 persen. Penggunaan instrument perbankan syari'ah telah menunjukkan relevansi yang signifikan bagi proses pembangunan nasional yang sedang berjalan saat ini. Pembiayaan perbankan syariah hingga akhir 2012 menunjukkan peningkatan pada pembiayaan modal kerja yang mayoritas atau sekitar 60 persen disalurkan pada usaha mikro dan kecil. Pertumbuhan DPK (dana pihak ketiga) yang cukup tinggi disalurkan sepenuhnya dalam bentuk berbagai bentuk pembiayaan. ${ }^{33}$

\footnotetext{
${ }^{30}$ Bunyi Pasal : "perbankan Syari'ah bertujuan menunjang pelaksanaan pembangunan nasional dalam rangka meningkatkan keadila, kebersamaan, dan pemerataan kesejahteraan rakyat."

${ }^{31}$ http://demo.jurnas.com/halaman/4/2013-11-18/274635,akses: 1 desember 2013

${ }^{32}$ ibid

${ }^{33}$ ibid
} 
Iri Hamzah, Muhammad Said Y, Shirhi Athmainnah : Konsep Perbankan Syari'ah ...

Dengan melihat perkembangan ekonomi syari'ah secara umum, dan perbankan syari"ah secara khusus. Maka sejatinya proses pembangunan yang sedang berjalan dapat semakin ditingkatkan khususnya terkait orientasi pembangunan yang pro-poor, pro-job, dan pro-growth. Kontribusi nyata ekonomi syariah dalam proses pembangunan nasional menjadi kekuatan untuk terus mendorong pertumbuhan ekonomi syariah di Indonesia. Dengan mendorong perkembangan ekonomi syariah, inklusivitas pembangunan dapat terus ditingkatkan sekaligus mempercepat proses pemerataan pembangunan.

\section{Tinjauan Sosiologi Hukum Islam: Hukum sebagai Social Engineering}

Sosiologi hukum membahas pengaruh timbal balik antara perubahan hukum dan masyarakat. Perubahan hukum dapat mempengaruhi perubahan masyarakat, dan sebaliknya perubahan masyarakat dapat menyebabkan terjadinya perubahan hukum. ${ }^{34}$ Bila pendekatan ini diterapkan dalam kajian hukum Islam, maka tinjauan hukum Islam secara sosiologis dapat dilihat pada pengaruh hukum Islam pada perubahan masyarakat Muslim, dan sebaliknya pengaruh masyarakat Muslim terhadap perkembangan hukum islam. ${ }^{35}$

Hukum bisa saja digunakan sebagai social of engineering, dalam arti bahwa hukum digunakan sebagai suatu alat oleh agent of change. Agent of change atau pelopor perubahan adalah seseorang atau kelompok orang yang mendapatkan kepercayaan dari masyarakat atau pemimpin satu atau lebih lembaga-lembaga kemasyarakatan. Suatu perubahan sosial yang dikehendaki atau direncanakan, selalu berada dibawah pengendalian serta pengawasan pelopor perubahan tersebut. Cara-cara untuk mempengaruhi masyarakat dengan sistem yang teratur dan direncanakan terlebih dahulu, dinamakan social engineering atau social planning. 36

Sebagai contoh, jumlah universitas dan mahasiswa di Indonesia. Sebelum Undang-Undang No.22/1961 ditetapkan, terdapat 14 universitas negeri dengan 65.000 mahasiswa. Terlepas dari baik buruknya, sejak undang-undang tersebut ditetapkan, jumlah universitas negeri naik sampai menjadi 34 buah dengan 158.000 siswa. ${ }^{37}$

Perbankan syariah modern dan perkembangan di beberapa negara oleh karena bunga dalam islam tidak diperbolehkan dan haram, maka di sejumlah Negara Islam mulai timbul usaha-usaha untuk mendirikan lembaga bank alternatif non-ribawi. Hal ini terjadi setelah Negara-Negara muslim mendapatkan kemerdekaannya dari bangsa-bangsa eropa. Usaha modern pertama untuk mendirikan bank non bunga dilakukan di Malaysia pada pertengahan tahun 1940an, tetapi usaha tersebut tidak sukses. Eksperimen lainnya dilakukan di Pakistan pada tahun 1950an, dimana suatu lembaga perkreditan tanpa bunga

\footnotetext{
${ }^{34}$ Soerjono Soekanto, Pengatar Sosiologi Hukum, Jakarta: (Bhratara Karya Aksara, 1977), hlm. 15

${ }^{35}$ Sudirman Tebba, Sosiologi Hukum Islam, (Yogyakarta: Uii Press Indonesia, $\left.\quad 2003\right)$, hlm. ix

${ }^{36}$ Soerjono Soekanto, Pokok-pokok Sosiologi Hukum, Jakarta: (Jakarta :PT RajaGrafindo, 2006), hlm. 121122

${ }^{37}$ Ibid., hlm. 123
} 
Iri Hamzah, Muhammad Said Y, Shirhi Athmainnah : Konsep Perbankan Syari'ah ...

didirikan di pedesaan negara itu. Baru pada 1963 perbankan syari'ah pertama didirikan di Mesir dengan nama mit ghamr local saving bank yang menerapkan sistem bagi hasil, pada awalnya berdirinya bank ini disambut hangat oleh pelaku ekonomi di Mesir, namun sayang pada tahun 1967 terjadi kekacauan politik yang mengakibatkan Mit Ghamer di ambil alih oleh Bank of Egypt yang beroperasi menggunakan bunga. Kesuksesan Mit Ghamr nampaknya menjadi inspirasi bagi umat Islam di seluruh dunia, sehingga pada tahun 1975 terbentuklah IDB (Islamic Developement Bank) yang di prakarsai oleh OKI, bank ini bertujuan untuk menyediakan bantuan finansial (keuangan) bagi negara-negara anggota dan membantu pendirian Bank-bank syari'ah di negara masing-masing. Kini terbang syari'ah telah mengalami perkembangan yang cukup pesat dan menyebar kebanyak negara, bahkan kenegara-negara barat, adalah The Islamic Bank Internasional of Denmark tercatat sebagai bank islam pertama yang beroperasi di daratan eropa pada tahun 1983 bahkan kini bank-bank kelas dunia sebut saja HSBC. Citibank dan banyak lainnya mulai membuka windows syari'ah. ${ }^{38}$

Dengan adanya UU No. 21 Tahun 2008 (khususnya Pasal 3), maka sangat nampak geliat masyarakat untuk berduyun-duyun menggunakan sistem perbankan islam. Berdasarkan data perbankan syari'ah Indonesia pertumbuhan perbankan konvensional jauh ketinggalan oleh bank syari'ah dimana bank syari'ah mengalami pertumbuhan sekitar 40 persen pertahun dalam 10 tahun terakhir sementara perbankan konvensional hanya 20 persen. Dari data yang dikeluarkan oleh bank Indonesia bulan Oktober 2011, total Asset perbank syari'ah mencapai Rp 125,5 triliun mengalami peningkatan besar Rp 97,5 triliun dari tahun 2010 dan mencapai pasar sekitar 4 persen dari total industri perbank nasional. Pertumbuhan perbankan syari'ah tahun ini adalah yang tertinggi sejak tahun 2005. ${ }^{39}$

Sementara dari segi tingkat pengumpulan dana pihak ketiga dan pembiayaan ke masyarakat masing-masing mencapai Rp 97,8 triliun dan Rp 92,8 triliun dengan tingkat Financing to Deposit Rasio (FDR) berada pada kisaran 95,7 persen dan dari faktor kinerja perbankan syari'ah pada akhir september 2011 BOPO (Biaya Operasi Pendapatan Operasional), ROA (Return on Asset) dan NPF (Non Performancing Financing) masing-masing berada pada 77.5 persen, 1.8 persen dan 2.0 persen. ${ }^{40}$

Sementara berdasarkan dengan jumlah bank syari'ah di Indonesia jumlahnya tidak mengalami penambahan yang signifikan dari tahun 2010 ke 2011 dimana jumlah nya 11 Bank Umum Syariah (BUS) dan 23 Unit Usaha Syari'ah (UUS), namun untuk jumlah Badan Perkreditan Rakyat Syari'ah (BPRS) mencapai 153 yang mengalami penambahan 3 BPRS dari tahun 2011, dan dari jangkauan kisaran masing-masing 1.354,301 dan 362 dimana secara geografis sebarang jaringan kantor perbankan syari'ah yang telah menjangkau masyarakat di lebih 89 kabupaten/kota di provinsi. ${ }^{41}$

\footnotetext{
${ }^{38}$ Adiwarman A. Karim. Bank Islam ... ... ... ..., hlm. 22-23

${ }^{39} \mathrm{https}: / /$ saripedia.worpress.com/tag/perkembangan-ekonomi-syari'ah/.akses:1 Desember 2013

${ }^{40}$ Ibid.

${ }^{41}$ Ibid.
} 
Iri Hamzah, Muhammad Said Y, Shirhi Athmainnah : Konsep Perbankan Syari'ah ...

\section{E. Penutup}

Dalam sejarah perekonomian umat islam, pembiayaan yang di lakukan dengan akad yang sesuai syari'ah telah menjdi bagian dari tradisi umat Islam sejak zaman Nabi. Praktik-praktik seperti menerima penitipan harta, meminjam kan uang untuk keperluan konsumsi dan untuk keperluan bisnis, serta melakukan pengiriman uang telah lazim di lakukan sejak zaman Rasulullah SAW.

Berdirinya Bank Islam di Indonesia di pertegas dalam Munas IV MUI di hotel Sahid jaya jakarta tanggal 22-25 Agustus 1990. Atas dasar amanat Munas IV MUI inilah langkah untuk mendirikan Bank Islam di Indonesia di muali. Bank syari'ah lahir sebagai salah satu solusi alternatif terhadap pertentangan antara bunga bank dan riba.

Tujuan di dirikannya Bank Syari'ah adalah diarahkan dalam rangka meningkatkan keadilan, kebersamaan, dan pemerataan kesejahteraan rakyat. Tujuan ini tercantum dalam pasal 3 Undang Undang No. 21 2008. Dengan melihat data-data yang dipaparkan di atas, perbankan syari'ah tengah berperan aktif dalam mewujudkan pembangunan nasional yang berkeadilan.

\section{Daftar Pustaka}

A . Karim, Adiwarman, Bank Islam: Analisis Fiqih Dan Keuangan, Jakarta: Pt Rajagrafindo Persada, 2007.

Abdullah, Mal An, Corporate Govermance Perbankan Syari'ah Di Indonesia, Yogyakarta: Ar-Ruzz Media Group, 2010.

Anshori, Abdul Ghafur, Pembentukan Bank Syari'ah Melalui Akuisi Dan Konversi (Pendekatan Hukum Positif Dan Hukum Islam), Yogyakarta: UII Press, 2010.

Antonio, Muhammad Syafi'i, Bank Syari'ah Dari Teori Ke Praktek: Gema Insani Press, 2003.

Arief, Sritua, Pembangunanisme Dan Edukasi Indonesia (Pemberdayaan Rakyat Dalam Arus Globalisasi). Bandung: Zaman Wacana Mulia, 1998.

Bakri, Asafria Jaya, Konsep Maqashid Syari'ah Menurut Al-Syatibi, Jakarta: Pt Rajagrafindo Persada 1996.

Chapra, M. Umar, Islam Dan Pembangunan Ekonomi, Jakarta: Kencana, 2000.

Haq, Hamka, Al-Syathibi: Aspek Teologis Konsep Maslahah Dalam Kitab Al-Muwafaqat, Jakarta: Penerbit Erlangga, 2007.

Jundiani, Pengaturan Hukum Perbankan Syari'ah Di Indonesia, Malang:Uin Malang Press, 2009.

Kamil, Ahmad, Kitab Undang-Undang Hukum Perbankan Dan Ekonomi Syari'ah. Jakarta: Kencana Prenada Media Group, 2007.

Karim, Adiwarman A, Bank Islam Analisis Fiqh Dan Keuangan, Cet. Vii, Jakarta: Rajagrafindo Perseda, 2010.

Koto, Alaiddin, Ilmu Fiqih Dan Ushul Fiqih, Jakartta: Rajawali Press, 2006.

Lebacqz, Karen, Teori-Teori Keadilan: Analisis Kritis Terhadap Pemikiran J.S Mill, John Rawls, Robert Nozik, Reinhold Neibuhr, Jose Porfirio Miranda, Ter. Yuhdi Santoso, Bandung: Nusa Media 2011. 
Iri Hamzah, Muhammad Said Y, Shirhi Athmainnah : Konsep Perbankan Syari'ah ...

Mansur, Pandangan Islam Terhadap Pembangunan Nasional, Dapatermen Agama R.I, 1981.

Maula, Bani Syarif, Sosiologi Hukum Islam Di Indonesia: Studi Tentang Realiatas

Hukum Islam Dalam Konfigurasi Sosial Politik, Yogyakarta: Aditya Media Publishing,2010

Muhamad, Manajemen Bank Syari'ah, Yogyakarta: Upp Amp Ykpn, 2002

Sjahdeini, Suatu Remy, Perbankan Islam Dan Kedudukannya Dalam Tata Hukum

Perbankan Indonesia, Cet. III, Jakarta: Pustaka Utama Grafiti, 2007

Soekanto,Soerjono, Pengatar Sosiologi Hukum, Jakarta: Bhratara Karya Aksara, 1977.

Pokok- Pokok Sosiologi Hukum, Jakarta: Pt Rajagrafindo, 2006

Sumitro,Warkum, Asas-Asas Perbankan Islam Dan Lembaga- Lembaga Terkait(BAMUI, TAKAFUL Dan Pasar Modal Syarah'ah Di Indonesia, Jakarta: Rajagrafindo Persada, 2004

Tebba, Sudirman, Sosiologi Hukum Islam, Yogyakarta: Uii Press Indonesia, 2003. 